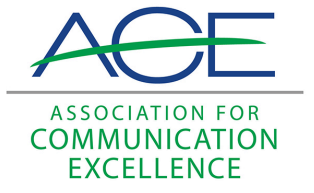

Journal of Applied Communications

\title{
Exploring the Relationship Between Pre-School-aged Animated Television and Agriculture: A Content Analysis of Disney Junior's Mickey Mouse Clubhouse
}

Cassaundra Dietrich

Emily Buck

Annie Specht

Follow this and additional works at: https://newprairiepress.org/jac

c) (1) (2)

This work is licensed under a Creative Commons Attribution-Noncommercial-Share Alike 3.0 License.

\section{Recommended Citation}

Dietrich, Cassaundra; Buck, Emily; and Specht, Annie (2015) "Exploring the Relationship Between PreSchool-aged Animated Television and Agriculture: A Content Analysis of Disney Junior's Mickey Mouse Clubhouse," Journal of Applied Communications: Vol. 99: Iss. 4. https://doi.org/10.4148/1051-0834.1065

This Research is brought to you for free and open access by New Prairie Press. It has been accepted for inclusion in Journal of Applied Communications by an authorized administrator of New Prairie Press. For more information, please contact cads@k-state.edu. 


\title{
Exploring the Relationship Between Pre-School-aged Animated Television and Agriculture: A Content Analysis of Disney Junior's Mickey Mouse Clubhouse
}

\begin{abstract}
Understanding how modern preschool television series are framing agriculture can help agricultural communicators and educators gain insight into what schemata preschoolers have developed about agriculture prior to participation in formal education and non-formal youth programming (such as 4-H). Framing theory and schema theory play a role in a developing child's absorption and interpretation of television programming content. Considering the potential implications of television consumption by preschoolers, this study aims to use summative content analysis methods to examine how agriculture is framed in current preschool-aged animated television programming. This analysis reviewed two iTunes collections of Mickey Mouse Clubhouse, each of which contained five episodes of the show. The two iTunes collections selected - "Mickey and Donald Have a Farm" and "Mickey's Farm Fun-Fair!" - were chosen because of their farm-centric themes. While content analysis revealed Mickey Mouse Clubhouse does frame agriculture in a positive context, it also uncovered a lack of depth in regard to educational lessons related to production agriculture. Additionally, several inaccuracies and improbable scenarios regarding production livestock, farm machinery and crops were discovered.
\end{abstract}

\section{Keywords}

Preschool, television, agriculture, Disney, Mickey Mouse Clubhouse, farm, framing theory, schema, animation, cartoons, Association for Communication Excellence Conference 


\section{Exploring the Relationship Between Preschool-aged Animated Television and Agriculture: A Content Analysis of Disney Junior's Mickey Mouse Clubhouse}

\section{Cassaundra Dietrich, Emily Buck, and Annie Specht}

\section{Abstract}

Understanding how modern preschool television series are framing agriculture can help agricultural communicators and educators gain insight into what schemata preschoolers have developed about agriculture prior to participation in formal education and non-formal youth programming (such as 4-H). Framing theory and schema theory play a role in a developing child's absorption and interpretation of television programming content. Considering the potential implications of television consumption by preschoolers, this study aims to use summative content analysis methods to examine how agriculture is framed in current preschool-aged animated television programming. This analysis reviewed two iTunes collections of Mickey Mouse Clubhouse, each of which contained five episodes of the show. The two iTunes collections selected - "Mickey and Donald Have a Farm" and "Mickey's Farm Fun-Fair!" - were chosen because of their farm-centric themes. While content analysis revealed Mickey Mouse Clubhouse does frame agriculture in a positive context, it also uncovered a lack of depth in regard to educational lessons related to production agriculture. Additionally, several inaccuracies and improbable scenarios regarding production livestock, farm machinery and crops were discovered.

\section{Key Words}

Preschool, television, agriculture, Disney, Mickey Mouse Clubhouse, farm, framing theory, schema, animation, and cartoons

\section{Introduction}

While television (TV) is still America's favorite entertainment pastime, overall viewership numbers continued on a declining trend in 2014 (Nielsen, 2014). Nielsen reported individuals spent more hours surfing the Internet and viewing streaming services and less time watching traditional television programming (Nielsen, 2014). In fact, about 2.6 million households are now "broadband only," meaning they don't subscribe to cable or pick up a broadcast signal (Nielsen, 2014). That figure is equivalent to approximately $2.8 \%$ of total U.S. households, more than double the $1.1 \%$ categorized as "broadband only" the previous year (Luckerson, 2014). Overall viewing of traditional TV also continues to shrink, with the average person watching about 141 hours of live television per month in 2014, compared with 147 hours per month in 2013 (Luckerson, 2014).

As the television media industry works to slow the decline in overall viewership, executives 
are looking to new audiences who remain loyal to television despite access to mobile media and streaming. One such market is preschool-aged children. Because their capabilities with mobile media and streaming are limited, "television continues to exert a strong hold over young children, who spend more time with this medium than any other" (Gutnick, Robb, Takeuchi, \& Kotler, 2011, p.7). A report by the Joan Ganz Cooney Center at Sesame Workshop found television consumption by preschoolers climbed to an average of 3.5 hours a day, an all-time high since the Sesame Workshop began tracking the statistic eight years prior (Gutnick, et al., 2011). A 2003 study by the Henry J. Kaiser Family Foundation found among children aged 0 to 6 approximately $77 \%$ turn on the TV by themselves; $71 \%$ ask for their favorite videos; $67 \%$ ask for particular shows; $62 \%$ use the remote to change channels; and $71 \%$ ask for their favorite videos or DVDs (Rideout, Vandewater and Wartella, 2003). This explosion of television use by young children since the start of the 21 st century has resulted in the creation of a number of television networks dedicated specifically for viewers aged 2 to 5 years, including Nickelodeon Junior, PBS Kids, Sprout, and Disney Junior (Yahr, 2012).

With television media placing such an emphasis on preschool-oriented programming, it is important to evaluate the content of these animated series. Understanding what preschoolers are learning and how it is absorbed in their schemata can be useful to educators and program administrators in filling gaps or correcting inaccuracies. In agriculture, consumer misinformation is a common and real threat as people become more and more removed from farming backgrounds and experiences. Today, more than $80 \%$ of the U.S. population lives in an urban area (U.S. Census Bureau, 2010). The ratio of U.S. citizens to U.S. farms is approximately 142:1, compared to $18: 1$ in 1935 (U.S. Environmental Protection Agency, 2013). In addition, the percentage of people farming for a living in the U.S. has declined from more than 30\% in 1914 to less than 2\% in 2014 (U.S. Department of Agriculture, 2014). This generational retreat from rural communities and farms to urban populations has resulted in a vast majority of children learning about agriculture solely through books, television and other media. Therefore, it is important to understand what children, distanced from farm and rural life, are learning about agriculture from their everyday cartoons.

\section{Theoretical Framework}

Evaluating how modern preschool television series are framing agriculture can help agricultural communicators and educators gain insight into what schemata preschoolers have developed about agriculture prior to participation in educational activities. Schemata are described as cognitive structures of preconceived ideas, which construct a framework representing aspects of the world (Zhao $\&$ Zhu, 2012). Schema theory states that, cognitively, humans develop a system of organizing and perceiving new information as they grow. "Schemas function as filters through which people order, interpret, and predict the world. Most people have developed schemas that help them to better understand themselves, the behavior of others, and events in the world" (Simpson, et al., 2013, p.17). Schemata also influence attention to and the absorption of new knowledge; studies show people are more likely to notice things that fit into their schema, while re-interpreting contradictions to the schema as exceptions or distorting them to fit. According to Padesky, co-founder of The Center for Cognitive Therapy, "Once formed, schemas are maintained in the face of contradictory evidence through the processes of distorting, not noticing, and discounting contradictory information or by seeing this information as an exception to the schematic, and therefore 'normative' rule" (1994, p. 268).

Developmentally, humans construct schema from the time they are born. Children under the age of 6 are considered to be highly impressionable, taking in their surroundings at astounding rates

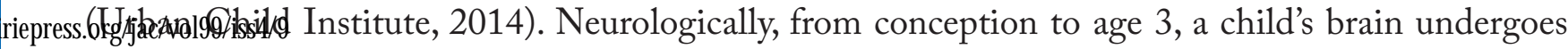


an impressive amount of change. At birth, the brain already contains almost all of the neurons it will ever have (Urban Child Institute, 2014). It doubles in size in the first year, and by age 3 it has reached 80 percent of its adult volume (Urban Child Institute, 2014). Additionally, from age 2 or 3 , the brain has twice as many synapses as it will have in adulthood (Li \& Sheng, 2003). This excess of synapses in the first three years makes the brain especially responsive to external input ( $\mathrm{Li} \&$ Sheng, 2003).

Considering the rapid construction of schema and the level of impressionability in preschoolers, it is important for agricultural communicators and educators to understand how modern children's television series are framing agriculture. Framing refers to mass communication's framing theory, which suggests how something is presented to an audience (the frame) influences how people process that information. Frames are thought to influence an audience's perception by not only telling the audience what to think about, but also how to think about the given subject or content (Scheufele, 1999). By gaining insight into the framing of agriculture in preschool television programming, agricultural communicators and educators can better anticipate the schema young children have formed about the industry prior to participation in school and extracurriculars.

\section{Purpose \& Research Objectives}

The purpose of this study was to evaluate the use of agriculture in Disney Junior's animated television program Mickey Mouse Clubhouse. This study was driven by the following research objectives:

1. Quantify the number of visual references made to agriculture, farming, production livestock or the like in Mickey Mouse Clubhouse's farm-centric themed collections, "Mickey and Donald Have a Farm" and "Mickey's Farm Fun-Fair!"

2. Describe the way in which Mickey Mouse Clubhouse frames agriculture in its farm-centric themed collections.

\section{Methodology}

For the purpose of this study, content for analysis was sampled from one television series on one network. In choosing the television series and network, ratings, viewership numbers and accessibility were considered. In October 2014, national ratings put the 24-hour Disney Junior channel at No. 1 for preschool-dedicated networks in total viewers $(494,000)$, children aged 2 to $5(243,000)$, and boys aged 2 to $2(122,000)$ for the nineteenth straight month (Lord \& McTeague, 2014). It was also reported to be the No. 1 preschool-dedicated network for the sixteenth straight month for girls aged 2 to $5(122,000)$ as well as No. 1 for the seventeenth straight month for women aged 18 to 49 (91,000) (Lord \& McTeague, 2014). Disney Junior programming is available in more than 98 million U.S. homes (McTeague, 2013). Internationally, its reach extends to 140 countries and 393 million households (McTeague, 2013). Of the series aired on the 24-hour Disney Junior channel, Mickey Mouse Clubhouse ranks first in total viewership for children aged 2 to 5 (Lord \& McTeague, 2014). The Emmy-award nominated series airs several days a week in multiple time slots per day (Disney Junior Media Net, 2014). Currently, 116 episodes of Mickey Mouse Clubhouse have been produced (TV Guide, 2015).

Due to their popularity, consistent viewership ratings and accessibility as well as their relevance to this study by having farm-centric themed collections, the 24-hour Disney Junior channel and Mickey Mouse Clubhouse were chosen. After determining which network and series would be used for the content analysis, the researchers searched iTunes to find episodes that contained content related to agriculture, farming, production livestock or the like. The iTunes search results included 
two episode collections with farm-centric themes. An iTunes collection is a group of episodes (in this case, five for each collection) that share related themes and/or character appearances. The episodes may be from various seasons of the show, but have been gathered into a "one-download" package for a viewer, similar to buying an album of music rather than a single song. The two episode collections identified in the search were "Mickey and Donald Have a Farm" and "Mickey's Farm Fun-Fair!" The collections were purchased and downloaded via iTunes for use in the study. The ten episodes included in the two collections are listed in Table 1.

Table 1

List of Episodes, Season Aired, and Air Date

\begin{tabular}{lcc}
\hline Episode Name & Season & Air Date \\
\hline Mickey and Donald Have a Farm & Season 4 & $11 / 05 / 2012$ \\
Goofy's Petting Zoo & Season 1 & $03 / 09 / 2007$ \\
Clarabelle's Clubhouse Moosical & Season 2 & $02 / 21 / 2009$ \\
Goofy the Homemaker & Season 2 & $01 / 26 / 2008$ \\
Donald Hatches an Egg & Season 3 & $07 / 13 / 2012$ \\
Mickey's Farm Fun-Fair! & Season 4 & $08 / 16 / 2013$ \\
Clarabelle's Clubhouse Carnival & Season 2 & $05 / 10 / 2008$ \\
Mickey's Big Job & Season 2 & $06 / 23 / 2008$ \\
Goofy's Thinking Cap & Season 3 & $03 / 09 / 2012$ \\
The Go Getters & Season 3 & $09 / 26 / 2011$ \\
\hline
\end{tabular}

A summative content analysis research design was used to complete the study. Summative content analysis starts with identifying and quantifying certain words or content with the purpose of understanding the contextual use of the words or content. This quantification is an attempt not to infer meaning but, rather, to explore usage (Hsieh \& Shannon, 2005). In this study, summative content analysis was used to quantify how often Disney Junior's Mickey Mouse Clubhouse presented content related to agriculture and how that content was framed.

Two researchers watched each episode closely, quantifying and coding visual references made to agriculture, farming, production livestock or the like. In addition, for each episode, the researchers summarized and coded the plot, characters, setting, and framing of agricultural references, as they personally understood them. Finally, any stereotypes, misinformation, or other contextual uses relevant to this study were also logged and coded. Throughout the content analysis, the pair of researchers conducted coder checks to ensure reliability. After viewing all 10 episodes, the researchers compared coding and notes and used qualitative measures to evaluate the content and fulfill the study objectives.

\section{Findings}

This study is aimed to evaluate how agriculture is framed on one of Disney Junior's most popular shows, Mickey Mouse Clubhouse. The show, which features the Sensational Six (Mickey Mouse, Minnie Mouse, Pluto, Goofy, Daisy and Donald) as well as other characters, is a learning-focused series that presents audiences stimulating challenges built around a theme of the day:

Through a dynamic, play-along experience that transports them through locations, young 
viewers develop early math skills and learn to identify shapes, patterns and numbers and decipher picture puzzles. Mickey and his pals help advance and reinforce the episode's learning through handy gizmos and gear, including the Mousekedoer, Mouseketools and a transportable device called Toodles. (Disney Junior Media Net, 2014)

The show has a dialogue format, making it feel as though Mickey and his friends are talking directly to the viewer. Each episode begins with the Sensational Six singing the Mickey Mouse Clubhouse theme song and introducing themselves. Afterward, Mickey enters the clubhouse and announces the theme, setting or problem to be solved for the day. The gang calls on Toodles, its helpful, magical device, to introduce the Mousketools they will rely on to make it through the day successfully. After solving their problems, the group reunites and sings the closing "Hot Dog!" song, celebrating their daily accomplishments. Each episode runs approximately 24 minutes.

Of the 10 episodes analyzed, only two, "Mickey and Donald Have a Farm" and "Mickey's Farm Fun-Fair!" were set at the Clubhouse Farm. These were the two episodes that headlined the iTunes collections. Their plots were both centered in agriculture; several references to farming and production livestock were made during the episodes. In "Mickey and Donald Have a Farm," the friends, dressed in stereotypical "farm" boots, flannel shirts, cowboy-style hats and overalls, travel to the Clubhouse Farm via the "clickety-clack tractor" (a red compact utility tractor). The Clubhouse Farm features a barn, silo, chicken coop with egg chutes, apple orchard, and cornfield. It appears to house cows, pigs, chickens, rabbits, a horse, and a goat. Upon entering the farm, Mickey says, "Here, we grow fruits and vegetables and raise animals." Walking past the cows, which are brown and all have udders, Goofy stops and says, "Howdy, girls!" Then, the friends break into song, singing, "Mickey and Donald have a farm, meeska mouska doo, and on our farm we have lots of fun, meeska mouska doo."

Afterward, Clarabelle Cow, an anthropomorphized black bovine who loves music and has a band of chickens that follow her and sing, enters the scene. She introduces her singing chickens and says, "Little darlings are so happy when they sing, and when they are happy, we get more eggs." Things appear to be going smoothly on the farm, when suddenly a huge wind gust comes in and blows all the animals away. Sincerely worried, Mickey says, "That wind could really wreck the farm and if that happens, we won't have any food." The group gathers together and runs along to find the source of the wind. After determining the wind was a product of Peg-Leg Pete's windmill and shutting it down, Mickey and his pals go about finding the missing farmyard animals. They decide to plant lettuce and carrots to lure the animals back to the Clubhouse Farm. Using the clickety-clack tractor, Mickey plants seeds that immediately turn into carrots and lettuce when watered. As they plant and grow their vegetables, the group sings, "Growing vegetables on the farm is always lots of fun. Our tractor likes to plant the seeds and with a clickety-clack and a poppity-pop, things begin to grow."

As the lettuce and carrots pop up from the soil, the rabbits and goat appear. However, the horse can be heard, but not seen. Looking up, the group realizes the horse is balanced atop the Clubhouse barn on the weathervane. Using a blimp suit from the Mousketools, the horse is able to float down to the ground. The group moves on, finding the pigs in the chicken coop and helping them to slide down the egg chutes. They also sing a song to entice the chickens to come out of hiding. Counting the animals in their wagon, Mickey and his friends realize the last ones to be found are the cows. Looking up on the hill, Goofy sees "Mrs. Cow" swinging in a tire swing. The group uses another Mousketool, a fishing pole, to pull her out of the swing. To end the episode, the Sensational Six return the animals to their homes at the Clubhouse Farm and return to the Clubhouse to sing the "Hot Dog!" song. 
In "Mickey's Farm Fun-Fair!," the gang, again dressed in stereotypical "farm" apparel, drives the clickety-clack tractor to a fair at the Clubhouse Farm. The fair is held in a circular arena made of straw bales and features an egg and spoon race, ring the bell game, and bakeoff. During the bakeoff, one of Clarabelle Cow's singing chickens becomes surprised and lays a white egg on the stage. The rolling egg causes Clarabelle Cow to slip on stage and throw her "moo-muffins" everywhere. Mickey calls on Toodles to bring a Mousketool to help gather the moo-muffins up. Once the moo-muffins are collected, the group breaks into a "geometric jamboree," dancing on shapes while singing, "Hold onto your hats, hitch up your pants, we are doing the fun fair square dance." They follow the dance with a big fruit and vegetable contest. Minnie announces to the group her prize tomato, which is small and shriveled, is in need of water. The Mousketool collection comes to the rescue, bringing an elephant that suctions water out of a nearby pond and sprays it on Minnie's tomato. The tomato magically grows to three times its size and becomes vibrant red. The contest continues, and a new character, Willie the Giant, enters the fair. Willie brings a giant peach to the contest, but he drops it and it becomes a runaway peach. Luckily, the clickety-clack tractor saves the day by stopping the peach. The episode ends with all the characters winning a blue ribbon and singing the "Hot Dog!" song.

The remaining eight episodes featured a variety of animals; however, aside from featuring the animals, minor references were made to farming or animal agriculture. "Goofy's Petting Zoo," "Clarabelle's Clubhouse Moosical," "Clarabelle's Clubhouse Carnival," and "The Go Getters" featured one or more species of production livestock more than 50\% of the runtime. In "Goofy's Petting Zoo," Goofy is in charge of caring for eight cows, 10 pigs, and an elephant at the petting zoo. However, he falls asleep and the animals escape. In their search, they find the cows stranded on an island in the middle of a pond. They use a sailboat to bring four cows at a time back to shore. While being rescued, the cows stand on their hind legs and moo a happy tune. The pigs are found riding on a Ferris wheel being operated by Peg-Leg Pete and the elephant is hanging in a tree. The gang uses its Mousketools to round up the animals and return them to the petting zoo.

"Clarabelle's Clubhouse Moosical" begins with Clarabelle Cow wanting to host a musical. Unfortunately, her singing chickens have lost their voices and cannot put on the show. Clarabelle relies on the Sensational Six to help her put on the musical, in which they sing popular nursery rhymes. After the first performance, the chickens cluck, clap, cheer, and jump with excitement. However, after the second song, the chickens appear less well, sitting on chairs at a table and drinking what appears to be hot tea. By the time the production is over, the chickens are all better and are able to participate in the grand finale, singing along with all the friends.

In "Clarabelle's Clubhouse Carnival," Clarabelle Cow announces the chickens are running out of corn to eat. To get more corn, Mickey and Clarabelle decide to host a carnival where guests pay in corn to enter, eat, or play games. The chickens as well as a cow and pig hang around the carnival as the group spends the day trying to fill a giant jar with corn. Once it is full, they begin to celebrate, but something goes wrong. One of the carnival games zaps the jar, turning all the corn to popcorn. At first, the group is not sure what to do, but then they realize the chickens like the popcorn and can eat it instead.

"The Go Getters" features three giant baby chicks who have fallen from Willie the Giant's farm, which is set in the clouds. The Go Getters, a secret agent group made up of Minnie, Daisy and Clarabelle Cow, use their detective skills to find the giant baby chicks. They follow their footprints and the broken white eggshells from which they hatched to locate them and return them to Willie 
"Donald Hatches an Egg," “Mickey's Big Job," and “Goofy's Thinking Cap” featured one or more species of production livestock less than 50\% of the runtime. "Donald Hatches an Egg" features the gang as they try to find the mother of an egg Goofy found in the woods. The egg appears to prefer Donald caring for it because it "shivers" when he is near it. The group uses a scarf to keep the egg warm while they travel around and try to find its owner. They first check with the birds in the woods, but it does not belong to them. Then, they ask the chickens at the petting zoo. Gladys, the hen, tells Goofy in "chicken talk" the egg does not belong to anyone at the petting zoo. In a thought bubble, the friends compare their mystery egg to a chicken egg, seeing it is a different shape and color (the chicken egg is brown). The group moves to a turtle at the pond, but the egg does not belong to the turtle either. While the group stands around puzzled, the egg begins to crack and hatches a baby alligator. They take the alligator to the river and find its mother and two siblings there.

In "Mickey's Big Job," Willie the Giant asks Mickey to keep an eye on his giant farm in the clouds while he goes to visit his mother. Mickey and his pals use a hot air balloon to float up to the farm. Upon arrival, they find a list of chores tacked to the door of his red barn Willie left for them to complete while he was gone. The chores include cleaning Willie's room, watering his garden and feeding his giant chickens. The group completes the first two chores and then moves on to the chicken coop, where they find a bag of giant corn kernels. They feed the chickens, which lay brown eggs, five kernels apiece.

"Goofy's Thinking Cap" features the Sensational Six doing a scavenger hunt, hosted by Clarabelle Cow. The single reference to agriculture is made on the scavenger hunt list, when the group is instructed to find a giant egg. They float up to Willie the Giant's farm and ask to have an egg from his giant chicken coop. He obliges, and they go in the coop to collect a giant white egg.

The remaining episode, "Goofy the Homemaker," did not contain any references to farming or animal agriculture. Instead, the episode focuses on Goofy constructing a birdhouse for his new friends, Mama and Baby Red Bird. It is significant to note the inclusion of this episode in a farmcentric collection. While it did not feature farming or animal agriculture directly, the plot was focused on constructing housing for an animal species. Construction of barns and housing of animals is indirectly relative to an agricultural lifestyle.

During the content analysis, the researchers quantified by method of coding the visual references made to agriculture in the shows (see Table 2). 
Table 2

List Quantifying Visual References Made to Agriculture

\begin{tabular}{|c|c|}
\hline Reference Object & $\%$ of Episodes Viewed In \\
\hline Chickens & $70 \%$ \\
\hline Red Barn & $60 \%$ \\
\hline Clarabelle Cow & $60 \%$ \\
\hline White Eggs & $50 \%$ \\
\hline Silo & $40 \%$ \\
\hline Straw & $40 \%$ \\
\hline Cows (not including Clarabelle Cow) & $30 \%$ \\
\hline Pigs & $30 \%$ \\
\hline Cornfield & $30 \%$ \\
\hline Farmer & $30 \%$ \\
\hline Cowboy-Style Hat & $30 \%$ \\
\hline Corn Kernels (used as chicken feed) & $30 \%$ \\
\hline Tractor & $20 \%$ \\
\hline Rabbits & $20 \%$ \\
\hline Brown Eggs & $20 \%$ \\
\hline Apples & $20 \%$ \\
\hline Carrots & $20 \%$ \\
\hline Corn on the Cob & $20 \%$ \\
\hline Horse & $10 \%$ \\
\hline Goat & $10 \%$ \\
\hline Lettuce & $10 \%$ \\
\hline Carrots & $10 \%$ \\
\hline Apples & $10 \%$ \\
\hline Seeds & $10 \%$ \\
\hline Planting Rows & $10 \%$ \\
\hline Peppers & $10 \%$ \\
\hline Pumpkins & $10 \%$ \\
\hline Tomatoes & $10 \%$ \\
\hline Peaches & $10 \%$ \\
\hline
\end{tabular}

\section{Discussion}

The qualitative and quantitative data collected during the content analysis was used to describe the way in which Mickey Mouse Clubhouse frames agriculture in its farm-centric-themed collections. The content analysis revealed, in all 10 episodes, agriculture was framed in a generally positive context. Researchers determined the context to be positive because, aside from some implausible scenarios, farming and its related operations appeared to be enjoyable and entertaining for the characters. The positive framing was most apparent in the two collection headliners: "Mickey and Donald Have a Farm" and "Mickey's Farm Fun-Fair!" The catchy tunes sang by Mickey and his pals in "Mickey and Donald Have a Farm"proclaim "On our farm we have lots of fun," and "Growing vegetables on the farm is always lots of fun." Mickey also impresses on viewers the importance of

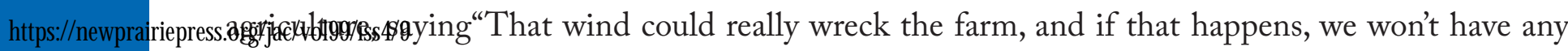


food." The group appears to enjoy working as they plant seeds, pick apples, and corral the livestock. The Clubhouse Farm is clean, organized and vibrant, and Mickey and his friends are dressed neatly. Additionally, the content analysis for this episode noted Goofy twice refers to Mickey's milking cows as female in gender. When entering the farm, Goofy says, "Howdy, girls!" Then, when he notices the cow stuck in the tire swing, he refers to her as "Mrs. Cow." Subtly slipping this agriculture fact (that only female species can be milked) into the episode is evidence of how preschool-dedicated networks can and are informally educating young children about agriculture.

In "Mickey's Farm Fun-Fair," an agricultural fair is accurately shown to be a lively place filled with games, food contests, animals, dancing, and awards. The other episodes also presented agriculture and production livestock in a positive context, showing Mickey and his friends engaging in delightful relationships with all of the animals they encounter. They commonly refer to the animals as "friends," "darlings," and "pals."

The content analysis did reveal a few instances of inaccuracies and unrealistic situations; however, some level of fantasy was to be expected because of the cartoon nature of the show. The most inaccurate and improbable scenes are listed as follows:

"Mickey and Donald Have a Farm"

- The clickety-clack tractor is a compact utility tractor that plants and waters seeds all in one motion. The planted seeds immediately turn into fresh produce upon being watered.

- The farm animals were picked up and carried away by a wind gust.

- The Clubhouse horse was found balancing on a weathervane atop of the barn.

- The Clubhouse pigs slide down the egg chutes to escape the chicken coop.

"Clarabelle's Clubhouse Moosical"

- Clarabelle Cow's chickens can sing, clap, bow, sit at a table, and drink from cups.

- Minnie's tomato magically grows to three times its size upon being watered.

- Clarabelle's Clubhouse Carnival:

- The corn kernels used as feed for the chickens turn into popcorn after being zapped by a carnival game (feed corn is not the same as popcorn).

"Goofy's Petting Zoo"

- Mickey and his friends are able to rescue the cows stranded on an island by putting them in a sailboat. As they return to shore, the cows stand on their hind legs and moo a tune.

- The pigs ride a Ferris wheel, each in their own car.

Other Episodes

- In five episodes, the red-and-brown-feathered chickens lay white eggs; however, in two other episodes, the same chickens' eggs are brown.

In the egg industry, red or brown breeds of hens do not produce white eggs. As the American Egg Board states, "The breed of hen determines the color of the shell. Among commercial breeds, hens with white feathers and ear lobes lay white-shelled eggs; hens with red feathers and ear lobes lay brown eggs" (2015). 


\section{Conclusions}

As agricultural communicators and educators, it is important to note the context and extent of agriculture's presence on TV. This content analysis only begins to unravel the framing and use of United States agriculture in preschool-aged animated television. As a $\$ 775.8$ billion industry that employs 16.5 million Americans (U.S. Department of Agriculture, 2014), agriculture plays a direct and essential part in the livelihoods of each citizen. With approximately 24 million children aged 0 to 5 living in the U.S. (U.S. Census Bureau, 2014), preschool-aged television offers agricultural communicators and educators a large platform for presenting young minds positive and accurate schemata about agriculture. Futhermore, parents of preschoolers who watch animated series alongside their children supply a secondary audience for informal agricultural education. The 24-hour Disney Junior channel was ranked as the No. 1 preschool-dedicated network for seventeen straight months for women aged 18 to 49 (91,000). This metric demonstrates uses and framing of agriculture on shows like Mickey Mouse Clubhouse are routinely reaching far more than just the average preschooler.

Fortunately, the writers for Mickey Mouse Clubhouse have presented agriculture and its likeness to preschoolers in a constructive and cheerful framework; however, the practicality and progressiveness of some scenes is questionable. For example, it would be more ideal to see Mickey driving a planting tractor or combine than a compact-utility tractor, which is reminiscent of antique farm equipment. Additionally, one specific element that appeared to be lacking was education specific to production. Though Mickey and his friends did a lot of teaching in regard to names, numbers, shapes, and colors, there was little to be learned about the farming operation. Expanding the lesson to include exercises that teach preschoolers why the different kinds of livestock are raised or the difference between feed corn and sweet corn (or white eggs versus brown eggs) would be a great way to introduce preschoolers and their growing schema to production agriculture. Even concepts as specific as using global positioning systems (GPS) on equipment, how grain is moved from the field to feed, or working in controlled environmental animal production facilities could be explored for subject matter.

\section{Recommendations}

The farm-centric scenes and references in Mickey Mouse Clubhouse and other similar preschool-aged animated television series are helping to plant the seed of what agriculture is like in the schema of thousands of preschoolers nationwide. Because schemata have a tendency to remain unchanged, even in the face of contradictory information, it is critical that, when possible, agricultural communicators and educators assist in the creation and production of such television series to ensure agriculture and production animals are portrayed accurately and positively.

Multiple recommendations originated as a result of this preliminary study. First, the researchers recommend additional in-depth studies be conducted to review other children's television programming as well as examine the semiotic meanings of the images portrayed through such shows. Second, future research related to this topic include experimental fieldwork that explicitly observes and/or interviews preschool-aged children. While content analysis establishes a foundation for evaluating agriculture's relationship with animated television programming, experimental research is much more ideal for understanding the perceptions and schemas actually being absorbed and constructed in the minds of young children. Sample hypotheses could explore whether animation of agriculture lessons improves understanding and permanence of content as well as if positive perceptions of agriculture are more probable when the lesson is taught by an already established, well-liked character (comparable to Mickey Mouse). Third, the researchers recommend more persuasive contact be made 
content in their shows. The researchers for this study, in a quest to determine what the show's content writers' backgrounds are in agriculture, did speak with the producer of Mickey Mouse Clubhouse, Mark Seidenberg; however, Seidenberg referred the researchers to ABC's legal department, who stated the group was unwilling to answer the questions posed. In the eyes of the researchers this is unfortunate because talks with Disney-ABC Television Group would provide more insight into the show curriculum and framing of episodes. Furthermore, contact with Disney-ABC Television Group could establish a porthole for the agriculture industry in regard to expanding educational resources for preschool-aged children via animated television. Speculation is that a large reputable group or organization (i.e. American Farm Bureau, USDA, National Education Association, etc.) might have more success coordinating talks with Disney-ABC Television Group. If a relationship with Disney$\mathrm{ABC}$ Television Group is beyond the industry's reach, it is proposed academics explore public arenas available for creating and disseminating accurate and exciting animated content to children. Public Broadcasting Service, YouTube, and preschools are possible platforms that may have an interest in non-profit educational content. Given an ideal funding and circulation situation, the researchers envision a modern day Schoolhouse Rock! focused on U.S. food production and distribution. Schoolhouse Rock! was an American interstitial series of animated musical educational shorts that originally aired during Saturday morning children's programming from 1973 to 1985 . The show is known for its memorability and recall capacities in viewers even 20 years after it first aired (Engstrom, 1995).

In conclusion, additional studies can assist agricultural communicators and educators in understanding what changes can be made to positively influence and expand agriculture's representation in all children's television media. Providing accurate and progressive agriculture lessons in cartoons is one potential way to initiate positive schema of agriculture and magnify agricultural education in the minds of young children.

\section{References}

American Egg Board. (2015). Incredible Edible Egg - Eggs - Color. Retrieved from http://www. incredibleegg.org/egg-facts/eggcyclopedia/c/color

Bloome, P. (1992). Seeking a Mature Relationship with Agriculture. Journal of Extension. 30(1). Retrieved from http://www.joe.org/joe/1992spring/tp1.php

Disney Junior Media Net. (2014). Mickey Mouse Clubhouse Fact Sheet. Retrieved from http://www. disneyjuniormedianet.com/web/showpage/showpage.aspx?program_id=900022\&type=factsheet Engstrom, E. (1995). Schoolhouse Rock: cartoons as education [Electronic Version]. Journal of Popular Film and Television, 23(3), 98-105.

Gutnick, A. L., Robb, M., Takeuchi, L., \& Kotler, J. (2011). Always connected: The new digital media habits of young children. New York: The Joan Ganz Cooney Center at Sesame Workshop.

Hsieh, H. F., \& Shannon, S. E. (2005). Three approaches to qualitative content analysis. Qualitative Health Research, 15(9), 1277-1288.

Li, Z., and Sheng, M. (2003). Some assembly required: the development of neuronal synapses. Nature Revierws, 4:833-841.

Lord, C., \& McTeague, P. (2014, October 28). Ratings Highlights for October 2014 - Final National Ratings. Retrieved from http://www.disneychannelmedianet.com/DNR/2014/DC_DJ_ OCT14.pdf

Luckerson, V. (2014, December 3). Fewer People Than Ever Are Watching TV. Time. Retrieved from http://time.com/3615387/tv-viewership-declining-nielsen/ 
McTeague, P. (2013, July). Disney Junior Fact Sheet. Retrieved from http://www.disneyjuniormedianet.com/facts/DJ_Fact_Sheet_March2013.pdf

Nielsen Holdings N.V. (2014). The Total Audience Report. Retrieved from http:/ir.nielsen.com/ files/doc_presentations/2014/The-Total-Audience-Report.pdf. 25.

Padesky, C.A. (1994). Schema Change Processes in Cognitive Therapy. Clinical Psychology and Psychotherapy, 1(5), 267-278.

Rideout, V. J., Vandewater, E.A. , and Wartella, E.A. (2003). Zero to Six: Electronic Media in the Lives of Infants, Toddlers and Preschoolers. The Kaiser Family Foundation. Retrieved from https:// kaiserfamilyfoundation.files.wordpress.com/2013/01/zero-to-six-electronic-media-in-thelives-of-infants-toddlers-and-preschoolers-pdf.pdf

Schor, J. (2004). Born to Buy: The Commercialized Child and the New Consumer Culture. New York: Scribner, p. 21.

Scheufele, D.A. 1999. "Framing as a Theory of Media Effects.” Journal of Communication, 49(4): 103-22.

Simpson, S. (2013), Vreeswijk, M. , Broersen, J. \& Nadort, M. (Eds.) (2012). The Wiley-Blackwell handbook of schema therapy, theory, research, and practice. Oxford, UK: Wiley-Blackwell. Clinical Psychologist, 17: 90. doi: 10.1111/cp.12018

TV Guide. (2015). Mickey Mouse Clubhouse Episode Guide. Retrieved fromhttp://www.tvguide. com/shows/mickey-mouse-clubhouse-280010/episodes/

U.S. Census Bureau. (2010). 2010 Census Urban and Rural Classification and Urban Area Criteria. Retrieved from https://www.census.gov/geo/reference/ua/urban-rural-2010.html

U.S. Census Bureau. (2014). Federal Interagency Forum on Child and Family Statistics. America's Children: Key National Indicators of Well Being, 2013. Washington, DC: U.S. Government Printing Office. Retrieved from www.childstats.gov/americaschildren/tables.asp

U.S. Department of Agriculture. (2014, March 28). Extension. Retrieved from http://www.csrees. usda.gov/qlinks/extension.html

U.S. Department of Agriculture. (2014, November 25). Ag and Food Sectors and the Economy. Retrieved from http://www.ers.usda.gov/data-products/ag-and-food-statistics-charting-theessentials/ag-and-food-sectors-and-the-economy.aspx

U.S. Environmental Protection Agency. (2013, April 4). Demographics. Retrieved from http:// www.epa.gov/oecaagct/ag101/demographics.html

Urban Child Institute. (2014). Baby's Brain Begins Now: Conception to Age 3. Retrieved from http://www.urbanchildinstitute.org/why-0-3/baby-and-brain

Yahr, E. (2012, June 22). A new boomlet in TV for preschoolers. The Washington Post. Retrieved November 30, 2014, from http://www.washingtonpost.com/entertainmentcf/tv/a-newboomlet-in-tv-for-preschoolers/2012/06/21/gJQA7ZB4uV_story.html Zhao, X., \& Zhu, L. (2012, September 12). Schema Theory and College English Reading Teaching. Canadian Center of Science and Education, 5(11), 112. doi:10.5539/elt.v5n11p111

\section{About the Authors}

Cassaundra Dietrich is a graduate research associate at The Ohio State University. Cassaundra graduated with her bachelor's degree in agricultural communications from OSU in 2009 and is now pursuing her Master of Science in agricultural communications. Cassaundra has worked as a graphic designer and marketing coordinator for Main Graphics in Urbana, Ohio, for six years and also as a

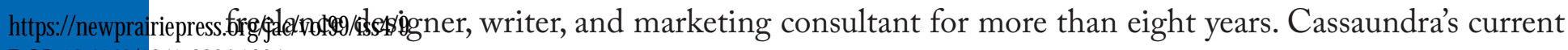


focus in her M.S. curriculum is public affairs, advocacy, marketing, and consumer behavior. She has a special interest in understanding public perceptions and expectations of the agriculture industry and how they be shaped to improve cognition and understanding of modern agriculture practices.

Emily Buck is an associate professor of agricultural communications at The Ohio State University. She has taught and conducted research at OSU for more than nine years in the area of agricultural perceptions and critical thinking involved in consumer problem solving. Buck has conducted similar surveys and focus groups around the world and has more than 34 professional research publications.

Annie Specht is an assistant professor of agricultural communications at The Ohio State University. Dr. Specht received her Ph.D.in Agricultural Leadership, Education, and Communication in 2013 from Texas A\&M University. Specht previously worked for the Department of Agricultural Leadership, Education, and Communication at the University of Nebraska-Lincoln (UNL). Her primary research interests are in the areas of visual communication, social semiotics, and discourse analysis of news and media portrayals of agriculture. At Texas A\&M, she investigated the use of Twitter to further communication and relationships among agriculture professionals. More specifically, Annie studied public misconceptions of H1N1 influenza outbreak and the public's association of "swine flu" with animal products. 